\title{
A COMPARISON OF ACTIVITIES OF METABOLIC ENZYMES IN LIZARDS AND RATS
}

\author{
ALBERT F. BENNETT* \\ Department of Zoology, The University of Michigan, Ann Arbor, Michigan 48104
}

(Received 21 December 1971)

\begin{abstract}
Protein-specific activities of metabolically important enzymes were measured in liver and skeletal muscle homogenates from three species of lizards, Sauromalus hispidus and Dipsosaurus dorsalis (Iguanidae) and Varamus gouldii (Varanidae), and laboratory rats.

2. Phosphofructokinase activity was relatively high in the muscle tissue of the iguanid lizards, which rely heavily on anaerobic metabolism during activity. Other enzymes had similar activities in all species of lizards.

3. The soluble (anaerobic) enzymes had equal activities in the lizards and the rat; however, the mitochondrial (aerobic) enzymes were approximately onefifth as active in the reptiles.

4. This differential activity parallels differences in organismal oxygen consumption and is probably due to a lower number of mitochondria in the reptilian tissue. The implications of this differential activity for the evolution of homeothermy are discussed.
\end{abstract}

\section{INTRODUC'TION}

EnZYMatic studies on reptilian tissues have been directed primarily toward the investigation of thermal rate dependence (Hussein, 1960; Licht, 1964, 1967; Abrahamson \& Maher, 1967) or heat denaturation (Licht, 1964; Ushakov, 1964; Precht, 1968); the regulation of metabolism in reptiles and differences between species of reptiles at the enzymatic level are almost completely uninvestigated. Furthermore, the enzymatic bases of the very large differential in organismal metabolic rate between reptiles and homeotherms-four- to tenfold (Dawson \& Bartholomew, 1956, 1958; Bartholomew \& Tucker, 1963; Templeton, 1970)have not been clarified. This study examines the specific activities of metabolically important enzymes in liver and skeletal muscle from lizards and from laboratory rats and attempts to contribute information to both these questions. The lizards investigated, Sauromalus hispidus and Dipsosaurus dorsalis (Iguanidae) and Varanus gouldii (Varanidae), have a differential reliance on anaerobiosis during activity. Varanus, a large carnivore, maintains high levels of oxygen consumption during activity and does not experience considerable lactic acid production (Bartholomew \& Tucker, 1964; Bennett, 1971). In contrast, iguanid lizards investigated (Moberly,

* Present address : Department of Zoology, University of California, Berkeley, California 94720. 
1968a, b; Bennett, 1971) rely heavily on anaerobic metabolism. This study was undertaken to determine whether these interspecific differences in oxygen utilization are reflected in the species enzymic complement.

Some enzymes examined in this study were selected on the basis of their function in regulating metabolic rate: phosphofructokinase, pyruvate kinase and NAD-linked isocitrate dehydrogenase* (Atkinson, 1966); others were chosen with regard to location within the cell or position within a metabolic pathway: lactic dehydrogenase, succinic dehydrogenase, NADP-linked isocitrate dehydrogenase and cytochrome oxidase. Most of these are considered indicator enzymes for a particular subcellular compartment (see Mahler \& Cordes, 1966, Table 9-2): soluble fraction-phosphofructokinase, pyruvate kinase and lactic dehydrogenase; mitochondrial fraction-succinic dehydrogenase, NAD-linked isocitrate dehydrogenase and cytochrome oxidase. The enzymes in the soluble fraction are involved in anaerobiosis and lactate production during activity; the mitochondrial enzymes are linked to oxygen as the terminal electron acceptor and, thus, operate aerobically. The locality of NADP-linked isocitrate dehydrogenase is variable between tissues and species (Pette, 1965; Visentin, 1969), and its distribution in reptilian tissue is unknown. Whole tissue homogenates (minus nuclei) of liver and skeletal muscle, the most metabolically interesting tissues, were used to avoid uncertainties in purification and to permit comparisons on the basis of total protein content of the tissue examined.

\section{MATERIALS AND METHODS}

Adult lizards were collected in the following localities: Dipsosaurus dorsalis, Palm Springs, Riverside Co., California; Sauromalus hispidus, Isla Mejia, Baja California Norte, Mexico; Varanus gouldii, widely scattered localities in the southern half of Western Australia. They were transported to the University of Michigan and maintained in a healthy condition in indoor cages until time of experimentation. Adult laboratory rats (Rattus norvegicus) were used as a representative mammal.

Animals, fasted at least 2 days, were killed rapidly by decapitation. Samples of liver and skeletal muscle (hind limb) were removed immediately, weighed and iced. All procedures involving the preparation of homogenates were carried out on ice or at $4^{\circ} \mathrm{C}$. The tissue samples were suspended in $0.25 \mathrm{M}$ sucrose in the proportion of $4 \mathrm{~cm}^{3}$ sucrose solution to $1 \mathrm{~g}$ tissue ( 20 per cent homogenate by weight). The liver samples were homogenized in a smooth glass homogenizer equipped with a loose-fitting Teflon pestle rotated at $600 \mathrm{rev} /$ $\mathrm{min}$. The skeletal muscle samples were ground in a small-capacity Waring Blendor for 10 sec to break down connective tissue elements. The samples were transferred to a glass homogenizer and treated as above. The samples were centrifuged at $4^{\circ} \mathrm{C}$ at $120 \mathrm{~g}$ for 10 min. The nuclear sediment was resuspended and recentrifuged at $120 \mathrm{~g}$ for $10 \mathrm{~min}$. The sediments were discarded and the supernatant fluids were used in the enzymatic analyses.

Determination of enzymatic activities was done according to the methods outlined for each enzyme. Concentrations are expressed in the total volume of the final reaction mixture. Doubling of enzyme concentration doubled the reaction rate over the time intervals and the range of substrate concentrations utilized; all reactions were run in duplicate. Sufficient

* Abbreviations used in this paper: ADP, adenosine diphosphate; AMP, adenosine-5'monophosphate; ATP, adenosine triphosphate; NAD, diphosphopyridine nucleotide; NADH, reduced diphosphopyridine nucleotide; NADP, triphosphopyridine nucleotide. 
time was allowed for the metabolism of endogenous substrates in the homogenate before the reaction was initiated. Determinations were made with a Beckman DB spectrophotometer and recorded on a Sargent recorder. Substrates, cofactors and enzymes were obtained from Sigma Chemical Corporation. All reactions except the cytochrome oxidase assay were run at $23^{\circ} \mathrm{C}$. Specific activities are expressed in n-moles of product formed per $\mathrm{min} / \mathrm{mg}$ protein nitrogen. Each assay was run on two to six animals of each species and the results expressed as the mean values observed.

Cytochrome oxidase (E.C. 1.9.3.1) was assayed by the method of Wharton \& Tozagoloff (1955). The reaction mixture contained: phosphate buffer, $\mathrm{pH} 7 \cdot 0,11 \mathrm{mM}$; and reduced ferrocytochrome-c, $0.033 \%$. The reaction mixture was incubated at $38^{\circ} \mathrm{C}$ for $5 \mathrm{~min}$ and the reaction was started by addition of the homogenate. Specific activity was determined from the rate of decrease in optical density at $550 \mathrm{~nm}$.

NAD-linked isocitrate dehydrogenase (E.C. 1.1.1.41) was assayed by a modification of the method of Ernster \& Navazio (1957). The reaction mixture contained: phosphate buffer, $\mathrm{pH} 6.5,20 \mathrm{mM} ; \mathrm{MgCl}_{2}, 1.7 \mathrm{mM} ; \mathrm{MnCl}_{2}, 0.17 \mathrm{mM} ; \mathrm{KCN}, \mathrm{pH} 7.5,0.50 \mathrm{mM}$; dichlorophenol indophenol, $0.030 \mathrm{mM}$; NAD, $0.17 \mathrm{mM}$; sodium DL-isocitrate, $6.7 \mathrm{mM}$; and homogenate. The reaction was initiated by the addition of the isocitrate and the decrease in optical density at $600 \mathrm{~nm}$ was used to calculate specific activity.

NADP-linked isocitrate dehydrogenase (E.C. 1.1.1.42) activity was determined according to the method of Kornberg (1955b). The reaction mixture contained: phosphate buffer, pH 7.5, $10 \mathrm{mM}$; NADP, $0.1 \mathrm{mM}$; $\mathrm{MgCl}_{2}, 3.3 \mathrm{mM}$; Triton X-100, 0.064\%; sodium DLisocitrate, $6.7 \mathrm{mM}$; and homogenate. The reaction was started by the addition of isocitrate and the increase in optical density at $340 \mathrm{~nm}$ was measured.

Lactic dehydrogenase (E.C. 1.1.1.27) was assayed according to the method of Kornberg (1955a). The reaction mixture contained: phosphate buffer, $\mathrm{pH} 7 \cdot 4,33 \mathrm{mM}$; NADH, $0.067 \mathrm{mM}$; sodium pyruvate, $0.33 \mathrm{mM}$; and homogenate. The reaction was started by the addition of pyruvate. The specific activity was measured from the decrease in optical density at $340 \mathrm{~nm}$.

Phosphofructokinase (E.C. 2.7.1.11) activity was determined with a modification of the method of Prichard \& Schofield (1968). The reaction mixture contained: imidazole buffer, $21 \mathrm{mM} ; \mathrm{MgCl}_{2}$, $5.2 \mathrm{mM}$; KCl, $209 \mathrm{mM}$; NADH, 0.050 mM; ATP, $1.0 \mathrm{mM}$; AMP, $2.1 \mathrm{mM} ; \mathrm{KCN}, \mathrm{pH} 7.5,0.31 \mathrm{mM} ; \alpha$-glycerophosphate dehydrogenase, 2.1 Units; glucose6-phosphate, $2.1 \mathrm{mM}$; and homogenate. The reaction was started by the addition of glucose6-phosphate; the decrease in optical density at $340 \mathrm{~nm}$ was used to calculate specific activity.

Pyruvate kinase (E.C. 2.7.1.40) was assayed with a modification of the method of Bücher \& Pfleiderer (1955). The reaction mixture contained: Tris- $\mathrm{HCl}$ buffer, $\mathrm{pH} 7 \cdot 5,35 \mathrm{mM}$; $\mathrm{MgSO}_{4}, 8.5 \mathrm{mM} ; \mathrm{KCl}, 80 \mathrm{mM}$; NADH, $0.053 \mathrm{mM}$; ADP, $0.24 \mathrm{mM}$; lactic dehydrogenase, 3.8 Units; phosphoenol pyruvate, $0.41 \mathrm{mM}$; and homogenate. The reaction was started by the addition of phosphoenol pyruvate. Decrease in optical density at $340 \mathrm{~nm}$ was used to determine specific activity.

Succinic dehydrogenase (E.C. 1.3.99.1) activity was measured according to the method of Singer \& Kearney (1957). The reaction mixture contained: phosphate buffer, pH 7.5, $39 \mathrm{mM}$; KCN, pH 7.5, $3.6 \mathrm{mM}$; dichlorophenol indophenol, $0.040 \mathrm{mM}$; phenazine methosulphate, $0.13 \mathrm{mM}$; sodium succinate, $\mathrm{pH} 7.5,26 \mathrm{mM}$; and homogenate. The reaction was started by the addition of succinate, and the decrease in optical density, read at $600 \mathrm{~nm}$, was used to calculate specific activity.

Protein determinations were made by the biuret reaction, according to Kabat \& Mayer (1961). Potassium deoxycholate ( $\mathrm{pH} 9 \cdot 0$, final concentration: $0.33 \%$ ) was added to the samples to decrease turbidity. The samples were placed in boiling water for $30 \mathrm{sec}$ and immediately iced. Liver samples were run through Millipore filters to remove residual turbidity. Samples of the homogenates and standards of purified bovine serum albumin (Armour) were read on a Beckman DB spectrophotometer at $540 \mathrm{~nm}$. 


\section{RESULTS AND DISCUSSION}

The protein-specific activities of the enzymes tested are reported in Tables 1 and 2 , and the activities of the reptilian enzymes are expressed as a percentage of the activities of the rat enzymes in Fig. 1. Because of the inherent variability in enzymic activity measurements, these results should be used only to reflect major differences between species or tissues. The rates are comparable for all tissues for a given enzyme, but differences between enzymes may reflect differences in assay procedures and not greater in vivo activity.

The present experiments are open to a number of objections: extrapolation from in vitro systems to in vivo conditions is always hazardous, and assays developed for mammalian or yeast enzymes may not be optimal for reptilian tissue. All enzymes except cytochrome oxidase were measured at room temperature. Although this is far below the activity temperatures of the lizards and normal body temperature of the rat, all of which approximate $38^{\circ} \mathrm{C}$, it is reasonable to assume that an equal temperature decrement would have approximately equal effects on the energy systems of the animals. Saturating concentrations of substrate were utilized in all experiments; the kinetics of non-saturated reptilian enzyme systems are unknown. The striking result, however, is the similarity of activity pattern within the soluble and mitochondrial fractions, respectively, of each species.

The glycolytic enzymes have much higher activities in skeletal muscle than in liver in all animals tested. The activity of the aerobic enzymes in the liver is nearly four times that in the muscle tissue. These observations are in accord with the decrease in oxygen availability during activity and consequent anaerobiosis in muscle tissue.

The most striking difference in the enzymatic complements of the different lizards is the comparatively high levels of phosphofructokinase activity present in the skeletal muscles of the iguanids. Phosphofructokinase is generally considered the rate-limiting enzyme in glycolysis (see Scrutton \& Utter, 1968), and a high in vivo activity of this enzyme would result in a capacity for rapid anaerobic catabolism of glycogen or glucose during physical activity. The higher activity present in iguanid muscles may be implicated in the formation of the large amounts of lactate present during activity in these animals. The other enzymes examined show no pronounced difference between the lizards.

The soluble enzymes and NADP-linked isocitrate dehydrogenase in the lizards, with the exception of muscle phosphofructokinase, have activities similar to those of the rat (i.e. within 50-175 per cent of the mammalian level). The activities of the mitochondrial enzymes are, however, considerably lower in the reptiles: NAD-linked isocitrate dehydrogenase and cytochrome oxidase are one-fifth as active as the mammalian enzymes. The activity of cytochrome oxidase is highly correlated with standard metabolic rate in several species of mammals and a turtle (Robin \& Simon, 1970), and a similar relationship was reported between cytochrome oxidase activity and standard and maximal metabolic rate in mammals (Jansky, 1962). The activities of the mitochondrial enzymes compare favorably with the observed six- to eightfold differences in organismal metabolic rates 
COMPARISON OF METABOLIC ENZYMES IN LIZARDS AND RATS

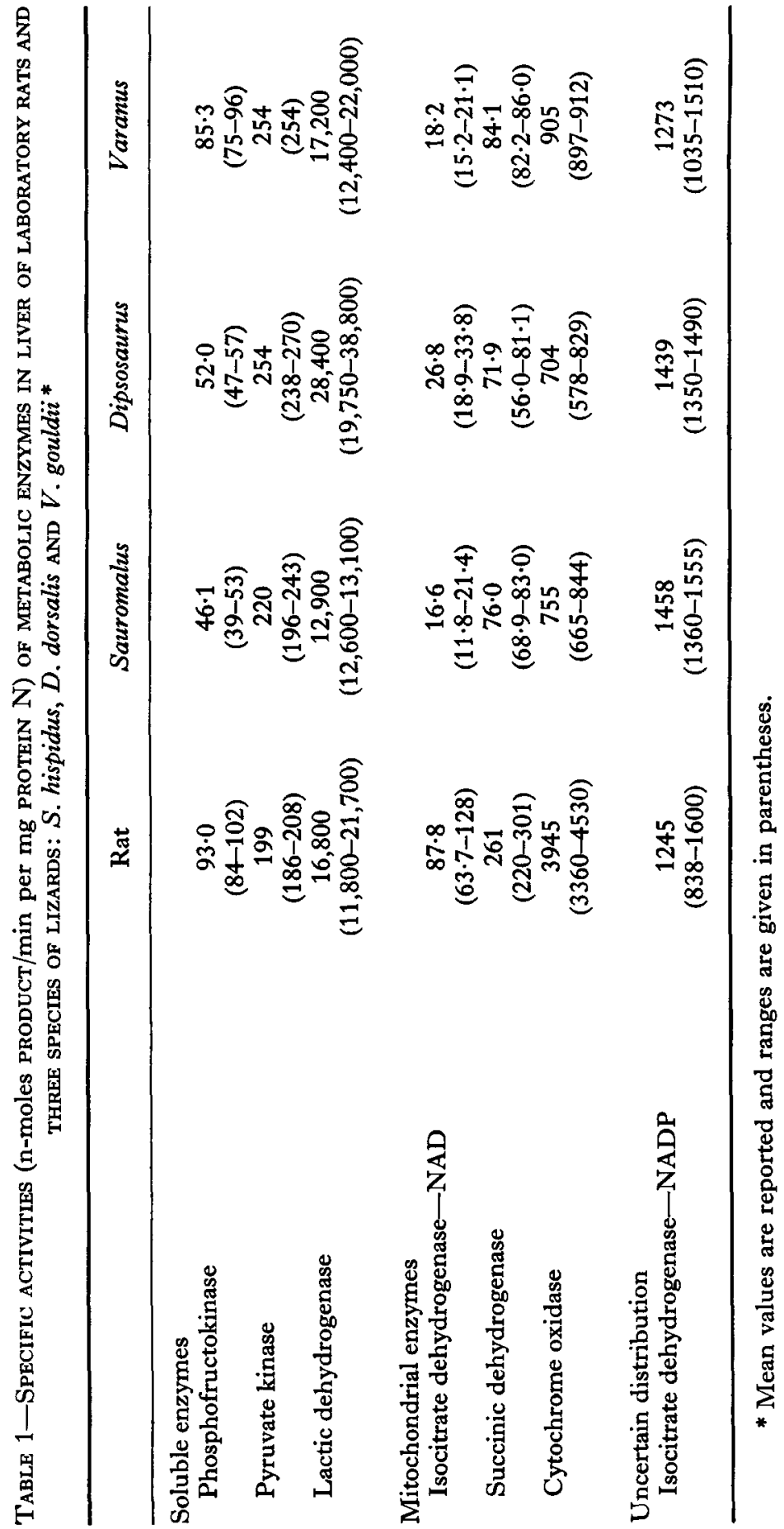




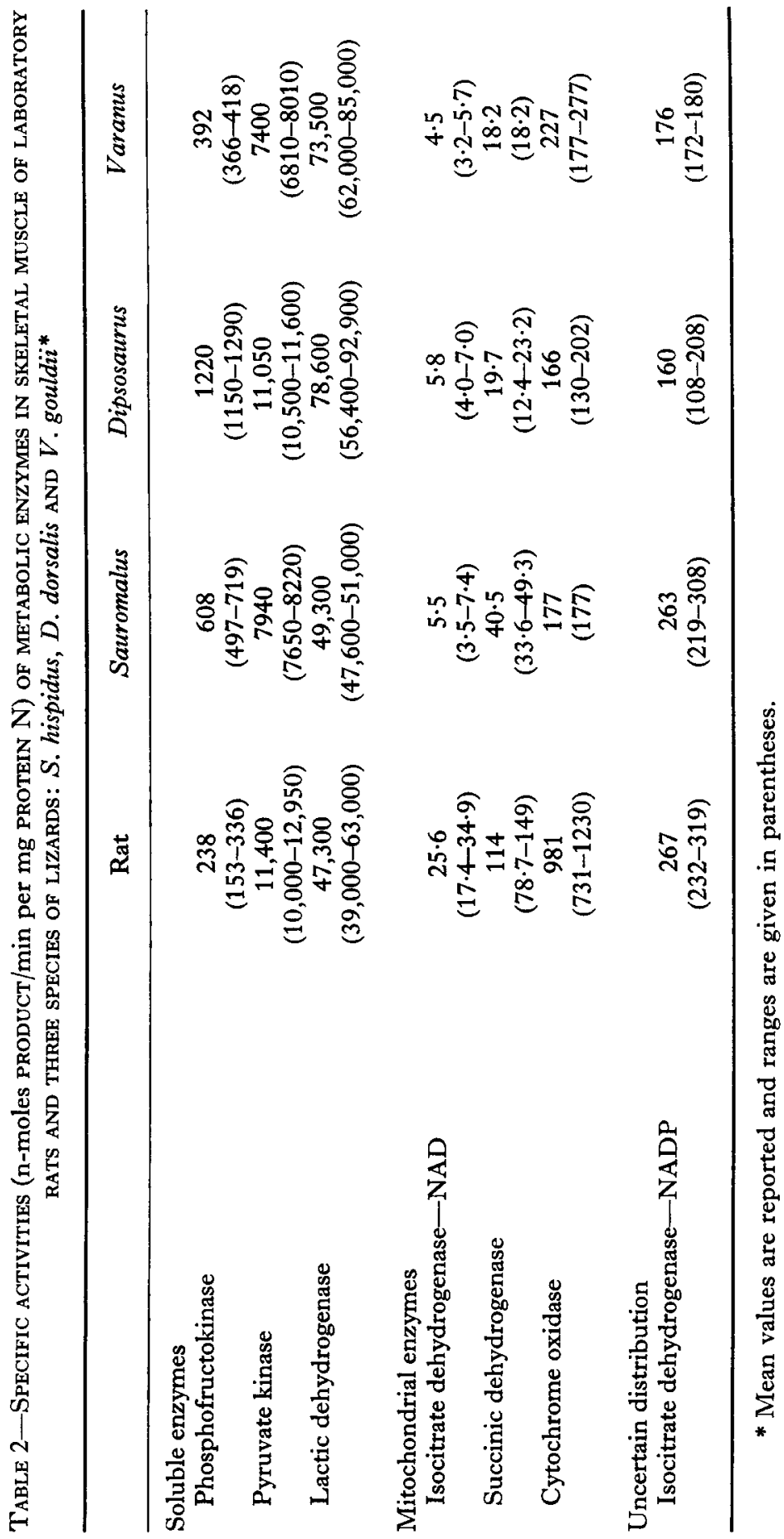




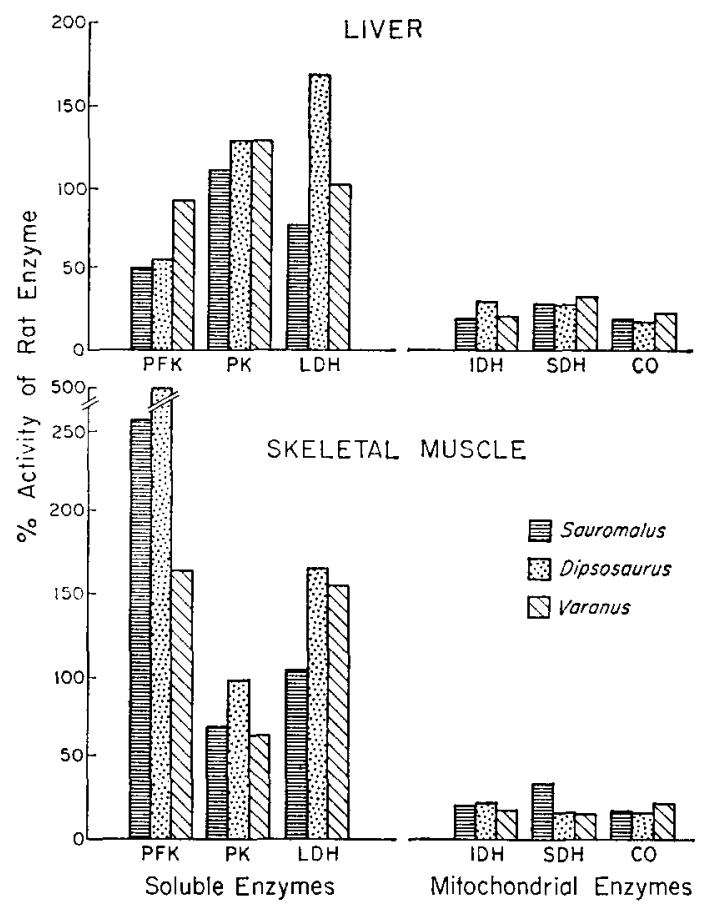

FIG. 1. Protein-specific activities of metabolic enzymes from three species of lizards expressed as a percentage of the activity measured in tissue from laboratory rats. Abbreviations: PFK, phosphofructokinase; PK, pyruvate kinase; LDH, lactic dehydrogenase; IDH, NAD-linked isocitrate dehydrogenase; $\mathrm{SDH}$, succinic dehydrogenase; $\mathrm{CO}$, cytochrome oxidase.

between these reptiles and comparably-sized homeotherms at the same body temperature (Dawson \& Bartholomew, 1958; Bennett, 1971).

The few studies which have involved both reptilian and mammalian or avian tissue in the same experiments support the conclusions reached in the present experiments. Lactic dehydrogenase levels in skeletal and cardiac muscle from rat and turtle (Pseudemys elegans) are equivalent (80-90 per cent) (Miller \& Hale, 1968). The activity of aldolase (fructose-1,6-diphosphate), an enzyme in the main glycolytic pathway, is essentially equal in samples comprised of representatives of three species each of reptiles (Lacerta agilis, Natrix natrix and Testudo hermanni), birds and mammals. Other enzymes examined in this study were outside of the main catabolic pathway, being associated with fructose metabolism, and the reptilian activities were appreciably below levels observed in birds and mammals (Heinz \& Weiner, 1969). A comparison of glucose metabolism in pectoral muscle of the lizard Uromastix hardwickii and rat diaphragm (Beloff-Chain \& Rookledge, 1970) found no qualitative differences in glucose catabolism but a much slower rate in the reptilian tissue; the rate of glycogen and lactate formation was one-fifth 
the rate in rat muscle at $37^{\circ} \mathrm{C}$, a situation again paralleling differences in organismal metabolic rate. Since these experiments were done aerobically, the glycolytic enzymes were undoubtedly under respiratory control; the results of a similar experiment performed anaerobically would be very interesting.

The higher activity of the mitochondrial enzymes in the rat might be due to a higher specific enzymatic activity per se, i.e. no difference exists in the number of enzyme molecules but each of them has a more rapid turnover of substrate. Alternatively, the amount of enzyme may be greater in rat tissue, either because of an increased amount of cristae within each mitochondrion or because of a greater number of mitochondria per $g$ of tissue. It is not possible at the present time to judge conclusively which of these is the primary factor; probably all of them are involved to a certain extent. Direct observations at $1000 \times$ magnification under polarized light revealed a much greater number of mitochondria, approximately three- to fivefold, in the homogenates of rat tissue than in those from the lizards. Mitochondria isolated from turtle heart (Chrysemys picta) have rates of utilization of tricarboxylic acid cycle intermediates equal to those isolated from mammalian cardiac muscle (Mersmann \& Privitera, 1964). Liver mitochondria from a lizard, Agama stellio, have rates of oxygen consumption on a protein basis equal to those from a mammal (Cassuto, 1971). The intensity of histochemical staining for succinic dehydrogenase in liver tissue is much greater in reptiles than in fish or amphibians, but is considerably less than in mammals (Hack \& Helmy, 1964). Histochemically determined concentrations of succinic dehydrogenase are equally high in reptilian, avian and mammalian red fibers in skeletal muscle; however, the proportion of red to white fibers appears higher in the tissues of the homeotherms (Ogata \& Mori, 1964). All these observations suggest that less enzyme, and not a lower specific activity per $s e$, is responsible for the lower activity found for the mitochondrial enzymes of the lizards. The number of mitochondria is known to reflect metabolic activity of individual tissues (Paul \& Sperling, 1952; Pette, 1965); Smith (1956) found the number of mitochondria per $g$ of tissue varies with body weight in the same proportion as standard metabolic rate in several species of mammals.

It is quite probable that the hiatus in organismal metabolic rates between reptiles and homeotherms is a reflection of a greater number of mitochondria per unit tissue weight in the latter and that this increment was one of the fundamental adjustments which occurred during the evolution of homeothermy. Bartholomew $\&$ Tucker (1963) postulated that an increased metabolic rate would be advantageous to a poikilothermic animal with a high thermal preferendum possessing a variable insulation, since it would provide an internal heat source and permit increased foraging time. An increased number of mitochondria would provide such a metabolic increment, while requiring little new genetic information, and presumably would represent a relatively easy evolutionary transformation. A larger number of mitochondria in homeothermic tissue may be related to the reliance of homeotherms on fatty acids as a metabolic substrate (Drummond, 1971); fatty acids are catabolized aerobically in the mitochondria. Fat deposits in reptiles are generally 
located in discrete storage sites, which appear to be used as reserves for periods of reproduction or scarcity of food (Dessauer, 1955; Hahn \& Tinkle, 1965; Smith, 1968). The role played by fats in reptilian metabolism is completely unknown and merits investigation.

Acknowledgements-This paper is part of a doctoral dissertation submitted to the Department of Zoology, University of Michigan. Financial support for this study was provided by four N.S.F. Graduate Fellowships (1966-70), N.S.F. Grant GB-3656 to Dr. William R. Dawson, the Graduate Student Research Fund of the Horace H. Rackham School of Graduate Studies and N.S.F. Grant GB-8212 to Dr. Nelson G. Hairston for research in Systematic and Evolutionary Biology. I am indebted to the Departments of Zoology at the Universities of Michigan and Western Australia for use of their facilities. In particular, I wish to thank Dr. William R. Dawson for his assistance and advice throughout my graduate tenure. Dr. Louis P. Visentin was most helpful in the formation of this project, and Drs. John M. Allen, Robert E. Beyer and George W. Nace generously provided laboratory facilities. I thank Dr. Paul Licht and Ms. Rudi Arnold for critically reading the manuscript.

\section{REFERENCES}

Abrahamson Y. \& Maher M. (1967) The effect of temperature upon pancreatic amylase in selected reptiles and an amphibian. Can. F. Zool. 45, 227-232.

Atkinson D. E. (1966) Regulation of enzyme activity. Ann. Rev. Biochem. 35, 85-124.

Bartholomew G. A. \& Tucker V. A. (1963) Control of changes in body temperature, metabolism, and circulation by the agamid lizard, Amphibolurus barbatus. Physiol. Zoöl. 36, 199-218.

Bartholomew G. A. \& Tucker V. A. (1964) Size, body temperature, thermal conductance, oxygen consumption, and heart rate in Australian varanid lizards. Physiol. Zoöl. 37, 341-354.

Beloff-Chain A. \& Rookledge K. A. (1970) A comparative study on the influence of temperature on the metabolism of glucose in isolated reptilian and mammalian muscle. Comp. Biochem. Physiol. 37, 67-72.

BeNNETT A. F. (1971) Oxygen transport and energy metabolism in two species of lizards, Sauromalus hispidus and Varanus gouldii. Ph.D. thesis, University of Michigan, Ann Arbor.

Bứcher T. \& Pfleiderer G. (1955) Pyruvate kinase from muscle. In Methods in Enzymology (Edited by Colowick S. P. \& Kaplan N. O.), Vol. 1, pp. 435-440. Academic Press, New York.

Cassuto Y. (1971) Oxidative activities of liver mitochondria from mammals, birds, reptiles and amphibia as a function of temperature. Comp. Biochem. Physiol. 39B, 919-923.

Dawson W. R. \& Bartholomew G. A. (1956) Relation of oxygen consumption to body weight, temperature, and temperature acclimation in lizards Uta stansburiana and Sceloporus occidentalis. Physiol. Zoöl. 29, 40-51.

Dawson W. R. \& Bartholomew G. A. (1958) Metabolic and cardiac responses to temperature in the lizard Dipsosaurus dorsalis. Physiol. Zoöl. 31, 100-111.

Dessauer H. C. (1955) Seasonal changes in the gross organ composition of the lizard, Anolis carolinensis. F. exp. Zool. 158, 79-86.

Drummond G. I. (1971) Microenvironment and enzyme function: control of energy metabolism during muscle work. Am. Zool. 11, 83-97.

Ernster L. \& Navazio F. (1957) Studies on TPN-linked oxidations-I. Pathways of isocitrate oxidation in rat liver mitochondria. Biochim. biophys. Acta 26, 408-415.

HACK M. H. \& HeLMY F. M. (1964) A comparative chemical study of the liver of various vertebrates. Acta histochem. 19, 316-328. 
Hahn W. E. \& Tinkle D. W. (1965) Fat body cycling and experimental evidence for its adaptive significance to ovarian follicle development in the lizard Uta stansburiana. $\mathcal{F}$. exp. Zool. 158, 79-86.

Heinz F. \& Weiner F. (1969) Enzymes of fructose metabolism in the liver of some vertebrates. Comp. Biochem. Physiol. 31, 283-296.

Hussein M. F. (1960) The influence of temperature on the activity of the pancreatic amylase of Uromastix aegyptia. Proc. Egypt. Acad. Sci. 15, 59-64.

JANSKY L. (1962) Maximal steady state metabolism and organ thermogenesis in mammals. In Comparative Physiology of Temperature Regulation (Edited by HanNoN J. P. \& VIERECK E.), Part 2, pp. 175-201. Arctic Aeromedical Laboratory, Alaska.

Kabat E. A. \& Mayer M. M. (1961) Experimental Immunochemistry, 2nd edn. Charles C. Thomas, Springfield, Illinois.

KorNBERg A. (1955a) Lactic dehydrogenase of muscle. In Methods in Enzymology (Edited by Colowick S. P. \& Kaplan N. O.), Vol. 1, pp. 441-443. Academic Press, New York.

KoRNBERG A. (1955b) Isocitric dehydrogenase of yeast (TPN). In Methods in Enzymology (Edited by Colowick S. P. \& Kaplan N. O.), Vol. 1, pp. 705-707. Academic Press, New York.

Licht P. (1964) The temperature dependence of myosinadenosinetriphosphatase and alkaline phosphatase in lizards. Comp. Biochem. Physiol. 12, 331-340.

Licht P. (1967) Thermal adaptation in the enzymes of lizards in relation to preferred body temperatures. In Molecular Methods of Temperature Adaptation (Edited by Prosser C. L.), pp. 131-145. Am. Assoc. Adv. Sci. Publ. 84.

Mahler H. R. \& Cordes E. H. (1966) Biological Chemistry. Harper and Row, New York.

Mersmann H. J. \& Privitera C. A. (1964) In vitro metabolism by turtle heart mitochondria. Am. F. Physiol. 206, 980-984.

Miller A. T., JR. \& Hale D. M. (1968) Comparisons of lactic dehydrogenase in rat and turtle organs. Comp. Biochem. Physiol. 27, 597-601.

MoBerly W. R. (1968a) The metabolic responses of the common iguana, Iguana iguana, to activity under restraint. Comp. Biochem. Physiol. 27, 1-20.

Moberly W. R. (1968b) The metabolic responses of the common iguana, Iguana iguana, to walking and diving. Comp. Biochem. Physiol. 27, 21-32.

Ogata T. \& Mori M. (1964) Histochemical study of oxidative enzymes in vertebrate muscles. F. Histochem. Cytochem. 12, 171-182.

Paul M. H. \& Sperling E. (1952) Cyclophorase system-XXIII. Correlation of cyclophorase activity and mitochondrial density in striated muscle. Proc. Soc. exp. Biol. Med. 79, 352-354.

Pette D. (1965) Plan und Muster im zellulären Stoffwechsel. Naturwiss. 52, 597-616.

PRECHT H. (1968) Der Einfluss "normaler" Temperaturen auf Lebensprozesse bei wechselwarmen Tieren unter Ausschluss der Wachstums- und Entwicklungs-Prozesse. Helgoländer Wiss. Meersunters. 18, 487-548.

Prichard R. K. \& Schofield P. J. (1968) The glycolytic pathway in adult liver fluke, Fasciola hepatica. Comp. Biochem. Physiol. 24, 697-710.

Robin E. D. \& Simon L. M. (1970) How to weigh an elephant: cytochrome oxidase as a rate-governing step in mitochondrial oxygen consumption. Trans. Ass. Am. Physns 83, 288-300.

SCUTTON M. C. \& UTter M. F. (1968) The regulation of glycolysis and gluconeogenesis in animal tissues. Ann. Rev. Biochem. 37, 249-302.

Singer T. P. \& KEARNEY E. B. (1957) Determination of succinic dehydrogenase activity. In Methods of Biochemical Analysis (Edited by GLICK D.), Vol. 4, pp. 307-333. Wiley, New York.

Smith R. E. (1956) Quantitative relations between liver mitochondria metabolism and total body weight in mammals. Ann. N.Y. Acad. Sci. 62, 403-422. 
SmIth R. E. (1968) Experimental evidence for a gonadal-fat body relationship in two teiid lizards (Ameiva festiva, Ameiva quadrilineata). Biol. Bull. 134, 325-331.

Templeton J. R. (1970) Reptiles. In Comparative Physiology of Thermoregulation (Edited by Whitrow G. C.), Vol. 1, Invertebrates and Nonmammalian Vertebrates, pp. 167-221. Academic Press, New York.

UsHakov B. (1964) Thermostability of cells and proteins of poikilotherms and its significance in speciation. Physiol. Rev. 44, 518-560.

VISENTIN L. P. (1969) A biochemical and morphological analysis of the renal and hepatic peroxisomes of the frog, Rana pipiens. Ph.D. thesis, University of Michigan, Ann Arbor.

Wharton D. C. \& TozagolofF A. (1955) Cytochrome oxidase from beef heart mitochondria. In Methods in Enzymology (Edited by Colowick S. P. \& Kaplan N. O.), Vol. 10, pp. 245-250. Academic Press, New York.

Key Word Index-Anaerobiosis; cytochrome oxidase; Dipsosaurus dorsalis; enzyme; glycolysis; homeothermy; isocitrate dehydrogenase; lactic dehydrogenase; lizard; mitochondria; muscle; oxygen consumption; phosphofructokinase; pyruvate kinase; reptile; Sauromalus hispidus; succinic dehydrogenase; tricarboxylic acid cycle; Varanus gouldii. 